medRxiv preprint doi: https://doi.org/10.1101/2021.09.07.21263100; this version posted September 12, 2021. The copyright holder for this preprint (which was not certified by peer review) is the author/funder, who has granted medRxiv a license to display the preprint in perpetuity. All rights reserved. No reuse allowed without permission.

\title{
Incidence of COVID-19 reinfection among Midwestern healthcare employees
}

Authors: Rivelli, Anne, MPH, MA ${ }^{1,2}$, Fitzpatrick, Veronica, DrPH ${ }^{1,2}$, Blair, Christopher, MS ${ }^{3}$, Copeland, Kenneth, $\mathrm{PhD}^{1,4}$, Richards, Jon, $\mathrm{MD}, \mathrm{PhD}^{1}$

\section{Affiliations:}

${ }^{1}$ Advocate Aurora Health, Downers Grove, IL, United States of America

${ }^{2}$ Advocate Aurora Research Institute, Downers Grove, IL, United States of America

${ }^{3}$ Takeda Pharmaceutical Company, Tokyo, Japan

${ }^{4}$ ACL Laboratories, Illinois and Wisconsin, United States of America

\section{Corresponding Author:}

Anne Rivelli, MPH, MA

Email: Anne.rivelli@aah.org

\section{Abstract}

Importance: Given the overwhelming worldwide rate of infection and the disappointing pace of vaccination, addressing reinfection is critical. Understanding reinfection, including protection longevity after natural infection, will allow us to better know the prospect of herd immunity, which hinges on the assumption that natural infection generates sufficient, protective immunity. The primary aim of this paper is to provide data on SARS-CoV-2 reinfection over a 10-month period.

Objective: The primary objective of this study is to establish the incidence of reinfection of COVID-19 among healthcare employees who experienced a prior COVID-19 infection. 
medRxiv preprint doi: https://doi.org/10.1101/2021.09.07.21263100; this version posted September 12, 2021. The copyright holder for this preprint (which was not certified by peer review) is the author/funder, who has granted medRxiv a license to display the preprint in perpetuity. All rights reserved. No reuse allowed without permission.

Design: This observational cohort study followed a convenience sample of 2,625 participants who experienced a COVID-19 infection for subsequent COVID-19 infection.

Setting: Healthcare employees were recruited across a large Midwestern healthcare system. Positive PCR test results were administered and recorded by the system-affiliated lab serving Illinois and Wisconsin.

Participants: Adult healthcare system employees who enrolled in a research study focused on SARS-CoV-2 antibodies $(\mathrm{N}=16,357)$ and had at least one positive PCR test result between March 1, 2020 and January 10, 2021 were included $(\mathrm{N}=2,625)$.

Exposure: Positive PCR test for SARS-CoV-2

Main Outcome(s) and Measure(s): The primary outcome is incidence of COVID-19 reinfection, defined by current CDC guidelines (i.e. subsequent COVID-19 infection $\geq 90$ days from prior infection). COVID-19 recurrence, defined as subsequent COVID-19 infection after prior infection irrespective of time, is also described.

Results: Of 2,625 participants who experienced at least one COVID-19 infection during the 10-month study period, $156(5.94 \%)$ experienced reinfection and 540 (20.57\%) experienced recurrence after prior infection. Median days were $126.50(105.50-171.00)$ to reinfection and $31.50(10.00-72.00)$ to recurrence. Incidence rate of COVID-19 reinfection was 0.35 cases per 1,000 person-days, with participants working in COVID-clinical and clinical units experiencing 3.77 and 3.57 times, respectively, greater risk of reinfection relative to those working in non-clinical units. Incidence rate of COVID-19 recurrence was 1.47 cases per 1,000 person-days. 
medRxiv preprint doi: https://doi.org/10.1101/2021.09.07.21263100; this version posted September 12, 2021. The copyright holder for this preprint (which was not certified by peer review) is the author/funder, who has granted medRxiv a license to display the preprint in perpetuity. All rights reserved. No reuse allowed without permission.

Conclusions and Relevance: This study supports the consensus that COVID-19 reinfection, defined as subsequent infection $\geq 90$ days after prior infection, is rare, even among a sample of healthcare workers with frequent exposure. 
medRxiv preprint doi: https://doi.org/10.1101/2021.09.07.21263100; this version posted September 12, 2021. The copyright holder for this preprint (which was not certified by peer review) is the author/funder, who has granted medRxiv a license to display the preprint in perpetuity. All rights reserved. No reuse allowed without permission.

\section{Introduction}

SARS-CoV-2, the virus that causes COVID-19, has been shroud in mystery since the first confirmed case was documented in Wuhan City, China in December 2019. A year and a half later, there have been over 190 million cases, 4 million deaths, and varying degrees of successful containment and mitigation. ${ }^{1}$ The ultimate goal is global herd immunity for COVID-19, with the two main paths to achieving herd immunity being natural infection and vaccination. ${ }^{2}$ After six months of mass vaccination efforts against SARS-CoV-2, preliminary data suggest extremely promising vaccine immunity results. However, while some countries have vaccinated more than half of their populations, many lag behind. ${ }^{3}$

Given the overwhelming worldwide rate of infection, especially with emerging variants, and the disappointing pace of vaccination, addressing reinfection is critical. Addressing reinfection, particularly the longevity of protection after natural infection, or natural immunity, will allow us to better understand the prospect of herd immunity, which hinges on the assumption that natural infection generates sufficient, protective immunity. ${ }^{2}$ The primary aim of this paper is to provide longitudinal data on natural immunity after SARS-CoV-2 infection.

The incidence of true COVID-19 reinfection is challenging to document, as the extensive resources necessary to confirm reinfection have not been available or practical to employ clinically. ${ }^{4}$ Confirmation of reinfection requires multiple polymerase chain reaction (PCR) tests, viral cultures, lab testing, and collection of clinical symptoms and epidemiological risk factors. ${ }^{4}$ This has subsequently led to probable under-reporting of reinfection in scientific journals, as evidence based on these inaccessible resources have been required for formal reporting of COVID-19 reinfection. ${ }^{5}$ Additionally, most individuals around the world who became infected during the first COVID-19 pandemic wave did not access a PCR or antibody test and/or were not treated in the hospital, delaying efforts to recognize and track overall COVID-19 reinfection early on in the pandemic. ${ }^{5-9}$ While the consensus is that reinfection is rare, more longitudinal studies focused on reinfection incidence in a variety of populations and time between confirmed infections will help corroborate this.,10-12 
medRxiv preprint doi: https://doi.org/10.1101/2021.09.07.21263100; this version posted September 12, 2021. The copyright holder for this preprint (which was not certified by peer review) is the author/funder, who has granted medRxiv a license to display the preprint in perpetuity. All rights reserved. No reuse allowed without permission.

The most up-to-date research suggests that infection provides natural immunity for at least three months ${ }^{13}$ and immunity remains stable up to 6-8 months after the initial infection. ${ }^{12,14}$ Furthermore, the maximum duration of SARS-CoV-2 ribonucleic acid (RNA) shedding in the upper respiratory tract, indicating recurrence, has been reported to be between 83 and 104 days, ${ }^{15-18}$ meaning positive retesting after roughly 3 months of a prior positive PCR test, along with clinical criteria, favors confirmation of reinfection. ${ }^{19}$

Based on the current available data, the Centers for Disease Control and Prevention (CDC) recently defined 90 days as the cut-off for retesting after a COVID-19 positive PCR test, given assumptions that primary infection can still result in a positive test for up to 90 days and that people with COVID-19 are protected from true reinfection for at least 90 days (Interim Guidance CDC). ${ }^{20}$ Additionally, one recent article proposed three detailed definitions of COVID-19 reinfection, specifically confirmed reinfection (characteristic clinical symptoms, positive PCR test result, positive viral culture if performed, $>90$ days from original infection, and viral RNA sequencing from both infections documenting unique strains); clinical reinfection (characteristic clinical symptoms, positive PCR test result, positive viral culture if performed, and epidemiological risk factor like known exposure with no other cause); and epidemiological reinfection (symptomatic or asymptomatic, positive PCR test result, positive viral culture if performed, and epidemiological risk factor like known exposure). ${ }^{4}$ Use of these definitions in research would promote more clarity and unity in results reporting. This study aims to contributes longitudinal data on epidemiological reinfection in a large cohort of healthcare workers in the United States (US) with documented cases of COVID-19, as defined by positive PCR test results. This study is an extension of two previous studies among the same cohort that addressed factors related to seroprevalence of SARS-CoV-2 Immunoglobulin G (IgG) ${ }^{21}$ and 3-month incidence of COVID-19 recurrence by SARS-CoV-2 IgG status. ${ }^{22}$ In this prior publication, recurrence was used as an umbrella term that comprised numerous scenarios, including persistent illness, prolonged viral RNA shedding, increased virus replication, a different symptomatic viral infection in the presence of remnant SARS-CoV-2 RNA, and/or true

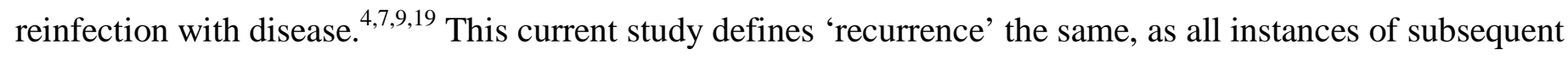
reinfection after initial infection during the study period. 
medRxiv preprint doi: https://doi.org/10.1101/2021.09.07.21263100; this version posted September 12, 2021. The copyright holder for this preprint (which was not certified by peer review) is the author/funder, who has granted medRxiv a license to display the preprint in perpetuity. All rights reserved. No reuse allowed without permission.

This study will address 10-month cumulative incidence of COVID-19 reinfection using the CDC's current guidelines. To provide context around reinfection, this study will also describe 10-month cumulative incidence of recurrence. We will also describe time to reinfection and recurrence, overall and stratified by clinical role in order to shine a light on the role of exposure frequency to SARS-CoV-2 in incidence and time to recurrence and reinfection.

\section{Methods}

This prospective cohort study recruited healthcare employees across a large Midwestern healthcare system, which consists of 26-hospitals and over 500 sites of care in Illinois and Wisconsin. SARS-CoV-2 IgG was measured in serum specimens obtained from all participants using the SARS-CoV-2 IgG Abbott Architect assay. Performance characteristics of the SARS-CoV-2 IgG assay were validated at ACL Laboratories, determining a sensitivity of $98.7 \%$ and specificity of $99.2 \% .^{23-24}$ To detect SARS-CoV-2, this study used the Aptima Panther SARS-CoV-2 Assay, which uses qualitative detection of RNA from SARS-CoV-2 isolated and purified nasopharyngeal, oropharyngeal and nasal swab specimens obtained from individuals who meet COVID-19 clinical and/or epidemiological criteria. ${ }^{25}$ Both the SARS-CoV-2 Antibody Assay and the Aptima Panther TMA SARS-CoV-2 Assay were approved for use under Emergency Use Authorization in US laboratories certified under the Clinical Laboratory Improvement Amendments of $1988 .{ }^{26}$ Prior to recruitment, this study obtained approval by the Institutional Review Board (\#20-168E).

\section{Participants}

This study includes English- and Spanish-speaking adults ages $\geq 18$ employed by the healthcare system as of June 8, 2020 (study initiation) who had at least one positive SARS-CoV-2 PCR test results in the system's Electronic Medical Record (EMR) system between March 1, 2020 and January 10, 2021. This sample of participants was drawn from the overarching study, which enrolled a convenience sample of 16,357 participants meeting the same inclusion criteria to test for SARS-CoV-2 IgG assay results between June 8, 2020 and July 10 , $2020 .^{21}$ After enrollment, all participants' positive SARS-CoV-2 PCR test results documented in the system's 
medRxiv preprint doi: https://doi.org/10.1101/2021.09.07.21263100; this version posted September 12, 2021. The copyright holder for this preprint (which was not certified by peer review) is the author/funder, who has granted medRxiv a license to display the preprint in perpetuity. All rights reserved. No reuse allowed without permission.

EMR between March 1, 2020 and January 10, 2021 were collected. It is implicit that team members were tested at a system-affiliated lab, if tested at all, due to no cost, convenience and employment implications.

\section{Procedures}

On June 6, 2020, a detailed recruitment email was sent to all team members' work email addresses. The email provided instructions for participation in the study, including an alteration of consent and a study-specific passcode required for study registration. Interested team members were instructed to register in their active online health portal. Team members who met study inclusion criteria and completed a lab blood draw to test for SARS-CoV-2 IgG were participants in this study.

\section{Variables}

Data gathered for this study included demographics and all system EMR-documented positive SARSCoV-2 PCR test results for COVID-19 infection between March 1, 2020 and January 10, 2021, including days between study initiation and each positive SARS-CoV-2 PCR test result. Age was collected as continuous and collapsed into standard reporting categories (ages 18-24; 25-34; 35-44; 45-54; 55-64; 65+). Race/ethnicity included Hispanic; White, Non-Hispanic; Black, Non-Hispanic; Asian, Non-Hispanic; American Indian, NonHispanic; or Mixed-race, Non-Hispanic (those who identified as two or more races). Sex included male and female. Clinical role category included COVID-clinical (participants working in a clinical capacity on COVID19 designated units), clinical (participants working in a clinical capacity on a non-COVID-19 designated unit) or non-clinical (participants in non-clinical roles, both remote and on-site). Number of days between participants' study initiation and positive SARS-CoV-2 PCR test results were used to calculate person-time at risk and days to reinfection and recurrence.

The primary outcome, incidence of COVID-19 reinfection, represents the second documented SARSCoV-2 positive PCR result for COVID-19 infection 90 or more days after a prior documented SARS-CoV-2 positive PCR result. For participants with more than two documented SARS-CoV-2 positive PCR results, the second documented infection that was closest to 90 or more days from the prior infection was included. For instance, one participant had seven total documented SARS-CoV-2 positive PCR results within the timeframe 
medRxiv preprint doi: https://doi.org/10.1101/2021.09.07.21263100; this version posted September 12, 2021. The copyright holder for this preprint (which was not certified by peer review) is the author/funder, who has granted medRxiv a license to display the preprint in perpetuity. All rights reserved. No reuse allowed without permission.

and their fifth documented infection was 92 days after their initial infection, so their initial and fifth infections and the days between were used in the reinfection analysis. This explains why there are more reinfection cases (156) than recurrence cases occurring at 90+ days (115). It should be noted that, if all first and last infections were included in reinfection analyses, there would be an additional 1162 person-days added to the overall person-time, reducing the incidence rate per 1,000 person-days a negligible amount. The secondary outcome, incidence of COVID-19 recurrence, represents the second documented SARS-CoV-2 positive PCR result after the initial documented SARS-CoV-2 positive PCR result, irrespective of time between positive results.

\section{Statistical methods}

Data management and analysis were performed by the study research team and conducted using SAS statistical software (Version 9.4; SAS Institute, Cary, NC).

Descriptive statistics are reported as counts (\%) or means (standard deviation) and median (interquartile range), as appropriate, particularly days to outcome. Demographic and baseline variables are also reported across primary and secondary outcome statuses. Corresponding measures of association include mean difference in age between those who did not experience reinfection or recurrence from those who did experience recurrence or reinfection and, for the remaining categorical variables, the odds ratio (OR), or the relative odds of participants of a given variable category experiencing COVID-19 recurrence or reinfection relative to the reference category of that variable. Variable reference levels were chosen based on lowest presumed risk. Corresponding p-values were generated from Student's T-tests for continuous variables and logistic regression Wald tests to represent differences in recurrence or reinfection.

Cumulative incidence of COVID-19 recurrence was calculated as number of participants who experienced a subsequent infection at/after 90 days of prior infection (reinfection) or who experienced a subsequent infection at all (recurrence) by total number of participants at risk of a subsequent infection between earliest positive PCR test result (March 1, 2020) and study end (January 10, 2021). Incidence rate (IR) was calculated as the number of participants at risk who experienced each outcome by person-days contributed to follow-up before the outcome was experienced or participant was censored at study end. The entire study period 
medRxiv preprint doi: https://doi.org/10.1101/2021.09.07.21263100; this version posted September 12, 2021. The copyright holder for this preprint (which was not certified by peer review) is the author/funder, who has granted medRxiv a license to display the preprint in perpetuity.

All rights reserved. No reuse allowed without permission.

was counted as 315 days (the number of days between earliest positive PCR test result and study end).

Incidence measures were calculated overall and by clinical role category. Incidence rate ratio (IRR) represents the relative IR between clinical role categories. Finally, categories of days to reinfection and recurrence are described as counts and percentages.

Role of the Funding source

This study was funded internally. The healthcare system had no influence over the study design, conduct, results, or dissemination of findings. The authors received no direct financial support for the research, authorship, and/or publication of this article.

\section{Results}

\section{COVID-19 Reinfection}

Among all 2,625 total participants who experienced COVID-19 infection, defined by on positive SARSCoV-2 PCR results, 156 (5.94\%) experienced COVID-19 reinfection after the initial infection, contributing 439,974 total person-days of follow-up until they reached reinfection or study end. Of these 156 participants who experienced reinfection, $42(26.92 \%)$ had COVID-clinical roles, $110(70.51 \%)$ had clinical roles, and 4 (2.56\%) had non-clinical roles within the healthcare system. Cumulative incidence of reinfection within 10 months was 5.94\% overall, 6.70\% among COVID-clinical participants, $6.23 \%$ among clinical participants, and $1.73 \%$ among non-clinical participants. IRRs indicated 3.77 times and 3.57 times increased risk of COVID-19 reinfection among COVID-clinical and clinical participants, respectively, relative to non-clinical participants.

\begin{tabular}{|c|c|c|c|c|c|}
\hline Variables of Interest & $\begin{array}{l}\text { Overall Sample } \\
\quad(N=2625)\end{array}$ & $\begin{array}{l}\text { COVID-19 Infection } \\
(N=2469 ; 94.06 \%)\end{array}$ & $\begin{array}{c}\text { COVID-19 Reinfection } \\
(N=156 ; 5.94 \%)\end{array}$ & $\begin{array}{c}\text { Measures of Association }^{\wedge} \\
(95 \% \text { CI })\end{array}$ & $P$-value \\
\hline Days to Reinfection & ( & ( & $\begin{array}{c}141.21(42.80) ; \\
126.5(105.5,171.0)\end{array}$ & $x_{1}$ & - \\
\hline 0-29 Days & - & - & $67(42.95 \%)$ & - & \multirow{4}{*}{ - } \\
\hline 30-59 Days & - & - & $27(17.31 \%)$ & - & \\
\hline 60-89 Days & - & - & $31(19.87 \%)$ & - & \\
\hline 90+ Days & - & - & $31(19.87 \%)$ & - & \\
\hline Age, mean (SD); median (IQR) & $\begin{array}{l}38.26(11.62) \\
36(29-47)\end{array}$ & $\begin{array}{l}38.29(11.68) \\
35(29-47)\end{array}$ & $\begin{array}{c}37.83(10.64) \\
36.5(29-46)\end{array}$ & $-0.46(-2.34,1.42)$ & 0.6313 \\
\hline $18-24$ & $200(7.62 \%)$ & $184(7.45 \%)$ & $16(10.26 \%)$ & REF & \multirow{6}{*}{0.2031} \\
\hline $25-34$ & $1040(39.62 \%)$ & $989(40.06 \%)$ & $51(32.69 \%)$ & $0.59(0.33,1.06)$ & \\
\hline $35-44$ & $634(24.15 \%)$ & $587(23.77 \%)$ & $47(30.13 \%)$ & $0.92(0.51,1.66)$ & \\
\hline $45-54$ & $417(15.89 \%)$ & $389(15.76 \%)$ & $28(17.95 \%)$ & $0.83(0.44,1.57)$ & \\
\hline $55-64$ & $306(11.66 \%)$ & $292(11.83 \%)$ & $14(8.97 \%)$ & $0.55(0.26,1.16)$ & \\
\hline $65+$ & $28(1.07 \%)$ & $28(1.13 \%)$ & $0(0.00 \%)$ & $<0.001(<0.001,>999.999)$ & \\
\hline Sex & & & & & \\
\hline
\end{tabular}


medRxiv preprint doi: https://doi.org/10.1101/2021.09.07.21263100; this version posted September 12,2021 . The copyright holder for this preprint (which was not certified by peer review) is the author/funder, who has granted medRxiv a license to display the preprint in perpetuity. All rights reserved. No reuse allowed without permission.

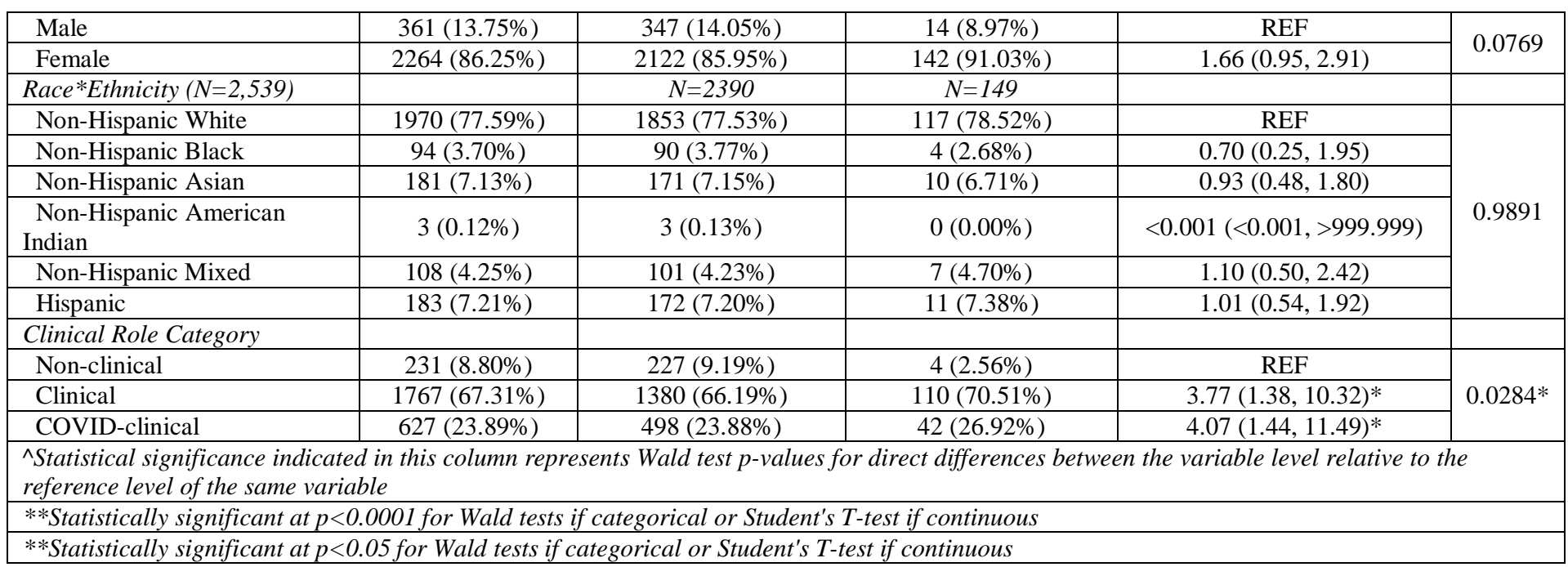

\begin{tabular}{|c|c|c|c|c|c|c|c|c|c|c|}
\hline REINFECTION & $\begin{array}{c}\text { At } \\
\text { Risk }\end{array}$ & Reinfection & $\begin{array}{c}\text { Person } \\
\text { Days }\end{array}$ & $\begin{array}{l}\text { Cumulative } \\
\text { Incidence }\end{array}$ & $\begin{array}{l}\text { IR Per 1,000 } \\
\text { Person-Days }\end{array}$ & IRR & 90-119 Days & 120-149 Days & 150-179 Days & 180+ Days \\
\hline Overall & 2625 & 156 & 439974 & $5.94 \%$ & 0.354566 & - & $67(42.95 \%)$ & $27(17.31 \%)$ & $31(19.87 \%)$ & $31(19.87 \%)$ \\
\hline \multicolumn{11}{|l|}{ Clinical Role } \\
\hline Non-Clinical & 231 & 4 & 38284 & $1.73 \%$ & 0.104482 & REF & $2(50.00 \%)$ & $0(0.00 \%)$ & $1(25.00 \%)$ & $1(25.00 \%)$ \\
\hline Clinical & 1767 & 110 & 295172 & $6.23 \%$ & 0.372664 & 3.57 & $48(43.64 \%)$ & $20(18.18 \%)$ & $21(19.09 \%)$ & $21(19.09 \%)$ \\
\hline COVID-Clinical & 627 & 42 & 106518 & $6.70 \%$ & 0.394300 & 3.77 & $17(40.48 \%)$ & $7(16.67 \%)$ & $8(19.05 \%)$ & $10(23.81 \%)$ \\
\hline
\end{tabular}

\section{COVID-19 Recurrence}

Among all 2,625 total participants who experienced at least one COVID-19 infection, 540 (20.57\%) experienced COVID-19 recurrence, contributing 368,085 total person-days of follow-up. Of these 540 participants who experienced recurrence, 129 (23.89\%) had COVID-clinical roles, 387 (71.67\%) had clinical roles, and $24(4.44 \%)$ had non-clinical roles within the healthcare system. Cumulative incidence of recurrence within 10 months was $20.57 \%$ overall, $20.57 \%$ among COVID-clinical participants, $21.90 \%$ among clinical participants, and $10.39 \%$ among non-clinical participants. IRRs indicated 2.07 times and 2.28 times increased risk of COVID-19 recurrence among COVID-clinical and clinical participants, respectively, relative to nonclinical participants.

\begin{tabular}{|c|c|c|c|c|c|}
\hline Variables of Interest & $\begin{array}{l}\text { Overall Sample } \\
\quad(N=2625)\end{array}$ & $\begin{array}{l}\text { COVID-19 Infection } \\
(N=2085 ; 79.43 \%)\end{array}$ & $\begin{array}{c}\text { COVID-19 Recurrence } \\
(N=540 ; 20.57 \%)\end{array}$ & $\begin{array}{c}\text { Measures of Association }^{\wedge} \\
(95 \% \text { CI })\end{array}$ & $P$-value \\
\hline Days to Recurrence & - & ( & $\begin{array}{l}53.43(57.88) ; \\
31.50(10-72) \\
\end{array}$ & 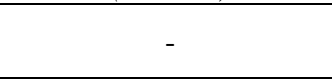 & - \\
\hline 0-29 Days & - & - & $257(47.59 \%)$ & - & \multirow{3}{*}{-} \\
\hline 30-59 Days & - & - & $116(21.48 \%)$ & - & \\
\hline 60-89 Days & - & - & $52(9.63 \%)$ & - & \\
\hline
\end{tabular}


medRxiv preprint doi: https://doi.org/10.1101/2021.09.07.21263100; this version posted September 12, 2021. The copyright holder for this preprint (which was not certified by peer review) is the author/funder, who has granted medRxiv a license to display the preprint in perpetuity. All rights reserved. No reuse allowed without permission.

\begin{tabular}{|c|c|c|c|c|c|}
\hline 90+ Days & - & - & $115(21.30 \%)$ & - & \\
\hline Age, mean (SD); median (IQR) & $\begin{array}{c}38.26(11.62) \\
36(29-47)\end{array}$ & $\begin{array}{c}38.42 \text { (11.78); } \\
36(29-47)\end{array}$ & $\begin{array}{c}37.64(11.00) \\
35(29-46)\end{array}$ & $-0.79(-1.89,0.31)$ & 0.1609 \\
\hline $18-24$ & $200(7.62 \%)$ & $151(7.24 \%)$ & $49(9.07 \%)$ & REF & \multirow{6}{*}{0.1735} \\
\hline $25-34$ & $1040(39.62 \%)$ & $832(39.90 \%)$ & $208(38.52 \%)$ & $0.77(0.54,1.10)$ & \\
\hline $35-44$ & $634(24.15 \%)$ & $492(23.60 \%)$ & $142(26.30 \%)$ & $0.89(0.61,1.29)$ & \\
\hline $45-54$ & $417(15.89 \%)$ & $332(15.92 \%)$ & $85(15.74 \%)$ & $0.79(0.53,1.18)$ & \\
\hline $55-64$ & $306(11.66 \%)$ & $252(12.09 \%)$ & $54(10.00 \%)$ & $0.66(0.43,1.02)$ & \\
\hline $65+$ & $28(1.07 \%)$ & $26(1.25 \%)$ & $2(0.37 \%)$ & $0.24(0.05,1.04)$ & \\
\hline \multicolumn{6}{|l|}{ Sex } \\
\hline Male & $361(13.75 \%)$ & $295(14.15 \%)$ & $66(12.22 \%)$ & REF & \multirow{2}{*}{0.2471} \\
\hline Female & $2264(86.25 \%)$ & $1790(85.85 \%)$ & $474(87.78 \%)$ & $1.18(0.89,1.58)$ & \\
\hline \multicolumn{6}{|l|}{ Race $*$ Ethnicity $(N=2,539)$} \\
\hline Non-Hispanic White & $1970(77.59 \%)$ & $1575(77.93 \%)$ & $395(76.25 \%)$ & REF & \multirow{6}{*}{0.7895} \\
\hline Non-Hispanic Black & $94(3.70 \%)$ & $76(3.76 \%)$ & $18(3.47 \%)$ & $0.94(0.56,1.60)$ & \\
\hline Non-Hispanic Asian & $181(7.13 \%)$ & $142(7.03 \%)$ & $39(7.53 \%)$ & $1.10(0.76,1.59)$ & \\
\hline Non-Hispanic American Indian & $3(0.12 \%)$ & $3(0.15 \%)$ & $0(0.00 \%)$ & $<0.001(<0.001,>999.999)$ & \\
\hline Non-Hispanic Mixed & $108(4.25 \%)$ & $80(3.96 \%)$ & $28(5.41 \%)$ & $1.40(0.90,2.18)$ & \\
\hline Hispanic & $183(7.21 \%)$ & $145(7.17 \%)$ & $38(7.34 \%)$ & $1.05(0.72,1.52)$ & \\
\hline \multicolumn{6}{|l|}{ Clinical Role Category } \\
\hline Non-clinical & $231(8.80 \%)$ & $207(9.93 \%)$ & $24(4.44 \%)$ & REF & \multirow{3}{*}{$0.0004 *$} \\
\hline Clinical & $1767(67.31 \%)$ & $1380(66.19 \%)$ & $387(71.67 \%)$ & $2.42(1.56,3.75)^{*}$ & \\
\hline COVID-clinical & $627(23.89 \%)$ & $498(23.88 \%)$ & $129(23.89 \%)$ & $2.23(1.40,3.56)^{*}$ & \\
\hline \multicolumn{6}{|c|}{$\begin{array}{l}\text { Statistical significance indicated in this column represents Wald test p-values for direct differences between the variable level relative to the reference } \\
\text { level of the same variable }\end{array}$} \\
\hline \multicolumn{6}{|c|}{ **Statistically significant at $p<0.0001$ for Wald tests if categorical or Student's T-test if continuous } \\
\hline \multicolumn{6}{|c|}{$* *$ Statistically significant at $p<0.05$ for Wald tests if categorical or Student's T-test if continuous } \\
\hline
\end{tabular}

\begin{tabular}{|c|c|c|c|c|c|c|c|c|c|c|}
\hline RECURRENCE & $\begin{array}{c}\text { At } \\
\text { Risk }\end{array}$ & Recurrence & $\begin{array}{l}\text { Person- } \\
\text { Days }\end{array}$ & $\begin{array}{l}\text { Cumulative } \\
\text { Incidence }\end{array}$ & $\begin{array}{l}\text { IR Per 1,000 } \\
\text { Person-Days }\end{array}$ & IRR & 0-29 Days & 30-59 Days & 60-89 Days & 90+ Days \\
\hline Overall & 2625 & 540 & 368085 & $20.57 \%$ & 1.467052 & - & $257(47.59 \%)$ & $116(21.48 \%)$ & $52(9.63 \%)$ & $115(21.30 \%)$ \\
\hline \multicolumn{11}{|l|}{ Clinical Role } \\
\hline Non-Clinical & 231 & 24 & 34490 & $10.39 \%$ & 0.695854 & REF & $16(66.67 \%)$ & $2(8.33 \%)$ & $2(8.33 \%)$ & $4(16.67 \%)$ \\
\hline Clinical & 1767 & 387 & 244048 & $21.90 \%$ & 1.585754 & 2.28 & $173(44.70 \%)$ & $88(22.74 \%)$ & $42(10.85 \%)$ & $84(21.71 \%)$ \\
\hline COVID-Clinical & 627 & 129 & 89547 & $20.57 \%$ & 1.440584 & 2.07 & $68(52.71 \%)$ & $26(20.16 \%)$ & $8(6.20 \%)$ & $27(20.93 \%)$ \\
\hline
\end{tabular}

\section{Conclusion}

\section{Primary Outcome: COVID-19 Reinfection}

Among the 2,625 total participants who experienced COVID-19 infection, 156 (5.94\%) experienced

COVID-19 reinfection, or a subsequent positive SARS-CoV-2 test result 90 or more days later. Median time to

recurrence was $126.50(105.50,171.00)$ days, with the majority of reinfection occurring between 90 and 119

days (42.95\%). Participants working in COVID-clinical roles showed the greatest cumulative incidence of

reinfection over 10 months $(6.70 \%)$ followed closely by participants working in clinical roles $(6.23 \%)$. Of those

who experienced reinfection, almost all (97.40\%) had COVID-clinical or clinical roles within the healthcare 
medRxiv preprint doi: https://doi.org/10.1101/2021.09.07.21263100; this version posted September 12, 2021. The copyright holder for this preprint (which was not certified by peer review) is the author/funder, who has granted medRxiv a license to display the preprint in perpetuity.

All rights reserved. No reuse allowed without permission.

system, which put individuals in clinical roles at more than 3.5 times increased risk of COVID-19 reinfection as compared with individuals working remotely or in non-clinical roles.

\section{Secondary Outcome: COVID-19 Recurrence}

Among the 2,625 total participants who experienced COVID-19 infection, 540 (20.57\%) experienced COVID-19 recurrence, or a subsequent positive SARS-CoV-2 PCR result. Median time to recurrence was 31.50 (10.00-72.00) days. The majority of recurrence was documented within 60 days of the initial infection (68.07\%), with most participants experiencing their second positive SARS-CoV-2 PCR test result within 30 days (47.59\%). Participants working in clinical roles showed the greatest cumulative incidence of recurrence over 10 months $(21.90 \%)$ followed closely by participants working in COVID-clinical roles (20.57\%).

\section{Discussion}

This study provides valuable data pertaining to the incidence and timing of COVID-19 reinfection and recurrence. Overall, this study corroborates previous studies that indicate reinfection is unlikely within a 10month period, but not impossible. Both reinfection and recurrence were much more likely in clinical roles - in both COVID-clinical and non-COVID clinical units. Reinfection and recurrence, however, need to be addressed separately since recurrence alone, without the context of time, does not provide much information about the risk of true reinfection and natural immunity.

\section{Reinfection}

Among the 2,625 total participants who experienced COVID-19 infection, 156 (5.94\%) experienced COVID-19 reinfection, two positive tests at least 90 days apart, per the CDC definition, and within 10 months of that initial infection. The overall IR per 1,000 person-days was very low, indicating reinfection is rare. Interestingly, when comparing different clinical roles, the IRRs suggested 3.77 times and 3.57 times increased risk of COVID-19 reinfection among COVID-clinical and clinical participants, respectively, relative to nonclinical participants. This demonstrates that consistent re-exposure in a clinical setting may increase risk of reinfection. This study could validate previous speculation that reinfection is increased by continued exposure to SARS-CoV-2, even after a previous infection. 
medRxiv preprint doi: https://doi.org/10.1101/2021.09.07.21263100; this version posted September 12, 2021. The copyright holder for this preprint (which was not certified by peer review) is the author/funder, who has granted medRxiv a license to display the preprint in perpetuity. All rights reserved. No reuse allowed without permission.

\section{Recurrence}

Among the 2,625 total participants who experienced COVID-19 infection, 540 (20.57\%) experienced COVID-19 recurrence, or at least two positive SARS-CoV-2 tests during this study period. Without viral testing, we don't know how many are accounted for by true reinfections or rather prolonged RNA shedding, persistent illness, or something else. Considering the difference in cumulative incidences between reinfection (5.94\%) and recurrence $(20.57 \%)$ shown in this study, it is likely that most recurrence in this study represents duplicate testing of the same infection, with the majority of recurrence occurring within 30 days (47.59\%) and 60 days of the initial infection (69.07\%). This, however, fails to explain why participants retested multiple times so close from the initial positive test. Return-to-work policies were based on resolution of COVID-19 symptoms and not retesting, even before the CDC released their 90-day retesting guidance. It is possible that healthcare workers had increased interest in their ongoing PCR test status and easier access to testing and, therefore, pursued retesting. As stated previously, this study did not assess symptomology or reasons for testing.

\section{Strengths}

This study enrolled and followed a large cohort of healthcare employees to determine risk of reinfection, as defined by the CDC, in a population likely to be re-exposed to COVID-19. This study provides much needed data to contribute to existing research on reinfection. PCR tests for COVID-19 infection were performed within system-affiliated labs, resulting in test performance and reporting consistency. All data was stored in EMR system and extracted by the healthcare system's analytics team, resulting in data collection consistency.

\section{Limitations}

There are several limitations to this study. Most important, there was no viral testing done to participants' blood samples, eliminating the ability to conclusively determine whether two SARS-CoV-2 test results in the same individual were due to true reinfection or recurrence. Second, abstracted data for this study did not include symptomatology; therefore, we cannot determine 1) reasons participants tested multiple times, 2) sickness severity of participants with positive SARS-CoV-2 test results, or 3) commonalities among individuals with positive results. This information could have contributed to the body of literature that correlates 
medRxiv preprint doi: https://doi.org/10.1101/2021.09.07.21263100; this version posted September 12, 2021. The copyright holder for this preprint (which was not certified by peer review) is the author/funder, who has granted medRxiv a license to display the preprint in perpetuity. All rights reserved. No reuse allowed without permission.

viral load with the ability to transmit the virus. ${ }^{27}$ Finally, because there is no universally accepted definition of reinfection, the study team used CDC retesting guidelines and some recently published guidance on proposed operational definitions of the terms to define reinfection and considered all subsequent positive test results to be recurrence.

\section{Implications}

Overall, this study indicates that reinfection is possible but unlikely, and both reinfection and recurrence are more likely among high-exposure groups like clinical healthcare workers. Individuals in high-exposure groups should continue to abide by previous public health precautions, irrespective of policy easement.

Widespread vaccination may be a solution to easing up on public health recommendations, but more long-term data is needed on vaccine efficacy, transmission and duration of protection in high exposure-risk populations. Vaccination rates will need to increase, as well, if we are ever to reach herd immunity since individuals will always be in higher-exposure groups. The current study end timeline was before the healthcare system began vaccinating front-line workers, which would have likely confounded the incidence of recurrence and reinfection. A future follow-up study using the same cohort will explore reinfection pre- and post-vaccination.

\section{Acknowledgements}

The authors would like to thank the many people at Advocate Aurora Health who supported this study, specifically the executive team who financially supported staff testing, Public Affairs and Marketing, Andy Marek and Chris Blumberg in Analytics, ACL leadership and staff, the Health Informatics Technology (HIT) team, Advocate Aurora Research Institute (AARI), IRB, and Maureen Shields for early work on this project. 
medRxiv preprint doi: https://doi.org/10.1101/2021.09.07.21263100; this version posted September 12, 2021. The copyright holder for this preprint (which was not certified by peer review) is the author/funder, who has granted medRxiv a license to display the preprint in perpetuity. All rights reserved. No reuse allowed without permission.

\section{References}

1. Johns Hopkins University \& Medicine. Coronavirus Cumulative Cases.

https://coronavirus.jhu.edu/map.html. Updated July 19, 2021. Accessed July 19, 2021.

2. Randolph HE, Barreiro LB. Herd immunity: Understanding COVID-19. Immunity. 2020 May 19;52:737-

741. doi: 10.1016/j.immuni.2020.04.012.

3. Ledford H. Six months of COVID vaccines: What 1.7 billion doses have taught scientists. Nature.

https://www.nature.com/articles/d41586-021-01505-x. Published June 4 2021. Accessed July 5, 2021.

4. Yahav D, Yelin D, Eckerle I, Eberhardt CS, Wang J, Cao B, et al. Definitions for coronavirus disease 2019 reinfection, relapse and PCR re-positivity. Clinical Microbiology and Infection. 2021;27:315-318. doi: 10.1016/j.cmi.2020.11.028.

5. Altmann DM, Boyton RJ, Beale R. Immunity to SARS-CoV-2 variants of concern. Science. 2021 Mar 12:371(6534):1103-1104. doi: 10.1126/science.abg7404.

6. Elsayed SM, Reddy MK, Murthy PM, et al. The possibility and cause of relapse after previously recovering from COVID-19: a systematic review. Cureus. 2020 Sept;12(9): e10264. doi: 10.7759/cureus.10264.

7. Kirkcaldy RD, King BA, Brooks JT. COVID-19 and post-infection immunity: limited evidence, many remaining questions. JAMA. 2020;323(22):2245-2246. doi:10.1001/jama.2020.7869.

8. Alwan NA, Burgess RA, Ashworth S, et al. Scientific consensus on the COVID-19 pandemic: we need to act now. The Lancet. 2020 Nov;396(10261):7-13.

9. Gousseff M, Penot P, Gallay L, Batisse D, Benech N, Bouiller K, et al. Clinical recurrences of COVID-19 symptoms after recovery: Viral relapse, reinfection or inflammatory rebound? J Infect. 2020 Nov;81(5);816846. doi: 10.1016/j.jinf.2020.06.073.

10. Joseph A. COVID-19 reinfections are rare - but without better data, we don't know how rare. STAT. https://www.statnews.com/2021/04/07/covid-19-reinfections-still-seem-rare/. Published April 7, 2021. Accessed July 19, 2021. 
medRxiv preprint doi: https://doi.org/10.1101/2021.09.07.21263100; this version posted September 12, 2021. The copyright holder for this preprint (which was not certified by peer review) is the author/funder, who has granted medRxiv a license to display the preprint in perpetuity. All rights reserved. No reuse allowed without permission.

11. Study finds COVID-19 reinfections are rare, more common for those above age 65. The Lancet.

https://www.eurekalert.org/pub releases/2021-03/1-tls031821.php. Published March 18, 2021. Accessed July 19, 2021.

12. Hall VJ, Foulkes S, Charlett A, Atti A, Monk EJM, Simmons R, et al. SARS-CoV-2 infection rates of antibody-positive compared with antibody negative health-care workers in England: A large, multicentre, prospective cohort study (SIREN). The Lancet. 2021 Apr 9;397(10283):1459-1469. doi: 10.1016/S01406736(21)00675-9.

13. Peltan ID, Beesley SJ, Webb BJ, Lopansri BK, Sinclair W, Jacobs JR, et al. Evaluation of potential COVID19 recurrence in patients with late repeat positive SARS-CoV-2 testing. PLoSONE. 2021;16(5):e0251214. doi: 10.1371/journal.pone.0251214.

14. Dan JM, Mateus J, Kato Y, Hastie KM, Yu ED, Faliti CE, et al. Immunological memory to SARS-CoV-2 assessed for up to 8 months after infection. Science. 2021 Jan 6. doi: 10.1126/science.abf4063.

15. Cevik M, Tate M, Lloyd O, Maraolo AE, Schafers J, Ho A. SARS-CoV-2, SARS-CoV-1 and MERS-CoV viral load dynamics, duration of viral shedding and infectiousness - a living systematic review and metaanalysis. The Lancet Microbe. 2021 Jan;2(1):e13-e22. doi: 10.1016/S2666-5247(20)30172-5.

16. Molina LP, Chow S-K, Nickel A, Love JE. Prolonged detection of severe acute respiratory syndrome coronavirus 2 (SARS-CoV-2) RNA in an obstetric patient with antibody seroconversion. Obstetrics \& Gynecology. 2020;Published Ahead of Print.

17. Liu W-D, Chang S-Y, Wang J-T, Tsai M-J, Hung C-C, Hsu C-L, et al. Prolonged virus shedding even after seroconversion in a patient with COVID-19. Journal of Infection. 2020 2020/08/01/;81(2):318-56.

18. Xiao AT, Tong YX, Zhang S. Profile of RT-PCR for SARS-CoV-2: A Preliminary Study From 56 COVID19 Patients. Clinical Infectious Diseases. 2020 Nov 19;71(16):2249-2251. doi: 10.1093/cid/ciaa460.

19. Falahi S, Kenarkoohi A. COVID-19 reinfection: Prolonged shedding or true reinfection? New Microbe and New Infect. 2020;38:100812. doi: 10.1016/j.nmni.2020.100812. 
medRxiv preprint doi: https://doi.org/10.1101/2021.09.07.21263100; this version posted September 12, 2021. The copyright holder for this preprint (which was not certified by peer review) is the author/funder, who has granted medRxiv a license to display the preprint in perpetuity. All rights reserved. No reuse allowed without permission.

20. Interim Guidance on Ending Isolation and Precautions for Adults with COVID-19. cdc.gov.

https:/www.cdc.gov/coronavirus/2019-ncov/hcp/duration-isolation.html. Updated March 16, 2021.

Accessed July 5, 2021.

21. Fitzpatrick V, Rivelli A, Blair C, Copeland K, Richards J. (2021). Disparities in seroprevalence of SARS-

CoV-2 immunoglobulin antibodies in a large midwestern health care system. Public Health Reports.

136(3):361-367. doi: 10.1177/0033354921999168.

22. Fitzpatrick V, Rivelli A, Blair C, Copeland K, Richards J. (2021). Incidence of COVID-19 recurrence among large cohort of healthcare employees. Annals of Epidemiology. 60:8-14. doi:

https://doi.org/10.1016/j.annepidem.2021.04.005.

23. Lieberman J, Pepper G, Naccache S, et al. Comparison of Commercially Available and Laboratory Developed Assays for in vitro Detection of SARS CoV-2 in Clinical Laboratories. J Clin Microbiol (2020); doi: 10.1128/JCM.00821-20.

24. Bryan A, Pepper G, Wener MH, et al. Performance Characteristics of the Abbott Architect SARS-CoV-2 IgG Assay and Seroprevalence in Boise, Idaho. J Clin Microbiol (2020). doi: 10.1128/JCM.00941-20.

25. SARS-CoV-2 IgG for use with Architect. U.S Food \& Drug Administration.

https://www.fda.gov/media/137383/download. Revised September 2020. Accessed July 29, 2020.

26. Coronavirus Disease 2019 (COVID-19) Emergency Use Authorizations for Medical Devices. U.S. Food and Drug Administration. https://www.fda.gov/medical-devices/emergency-use-authorizations-medicaldevices/coronavirus-disease-2019-covid-19-emergency-use-authorizations-medical-devices. Updated August 3, 2020. Accessed November 5, 2020.

27. Mahase E. COVID-19 Where are we on vaccines and variants. BMJ. 2021;372:n597. doi: 10.1136/bmj.n597. 